\title{
INSTITUTIONAL COORDINATION OF FLOOD CONTROL AT MEDAN CITY IN MEBIDANGRO COOPERATION SCHEME
}

\author{
Muhammad Husni Thamrin, Hatta Ridho and Faiz Albar Nasution \\ Fakultas Ilmu Sosial Dan Ilmu Politik, Universitas Sumatera Utara, Jl. Dr. A. Sofian No. 1A, Kota \\ Medan, Sumatera Utara, 20222 \\ E-mail:mhd.husni@usu.ac.id; ridhohatta71@gmail.com; faiz@usu.ac.id
}

\begin{abstract}
Flood management system in Medan City is very poor, because there is no institutional coordination resulting from sectoral egos. Effective institutional coordination in urban flood management is needed. Condition is based on problem of flooding in Medan City which has not been effectively implemented, so an alternative solution for integrated urban flood management is needed. Purpose of this research is to explain implementation of flood control policies in Medan City and how coordinate flood control institutions in Medan City in Mebidangro cooperation scheme. This type of qualitative research with descriptive methods is used in this research. Primary data collection techniques with deep interviews through FGD activities with stakeholders. In addition, secondary data is collected by citing journals, books, documents, online media, and other materials support research. Data analysis techniques are carried out through data reduction activities, data display and drawing conclusions. Results showed implementation Presidential Regulation No. 62 of 2011 on flood control in Medan City has not been optimally implemented. Condition is influenced lack of understanding authority and lack of coordination between related agencies to safeguard river basins, river norms and establish primary drainage channels. In addition, coordination of Medan City flood control institution in Mebidangro cooperation scheme has been carried out in a procedural manner. However, actualization still requires visionary leadership and command to support success program.
\end{abstract}

Keywords: Institutional Coordination; Flood Control; Mebidangro

\section{KOORDINASI KELEMBAGAAN PENGENDALIAN BANJIR DI KOTA MEDAN DALAM SKEMA KERJASAMA MEBIDANGRO}

\begin{abstract}
ABSTRAK. Sistem pengelolaan banjir di Kota Medan sangat buruk, sebab tidak adanya kordinasi kelembagaan yang diakibatkan dari ego sektoral. Oleh karena itu, koordinasi kelembagaan yang efektif dalam pengelolaan banjir perkotaan lebih dibutuhkan. Kondisi ini berdasarkan masalah banjir di Kota Medan yang belum efektifaktualisasinya, maka diperlukan solusi alternatif pengelolaan banjir perkotaan terpadu. Tujuan dalam penelitian ini adalah menjelaskan implementasi kebijakan pengendalian banjir di Kota Medan dan bagaimana kordinasi kelembagaan pengendalian banjir di Kota Medan dalam skema kerjasama Mebidangro. Jenis penelitian kulaitatif dengan metode deskriptif digunakan dalam penelitian ini. Teknik pengumpulan data primer dengan deep interview melalui kegiatan FGD terhadap pemangku kepentingan. Selain itu, data skunder dikumpulkan dengan mengutip jurnal, buku, dokumen, media online, serta bahan lain yang mendukung penelitian. Teknik analisa data dilakukan melalui aktivitas reduksi data, display data dan menarik kesimpulan. Hasil penelitian menunjukkan implementasi Peraturan Presiden Nomor 62 Tahun 2011 terhadap pengendalian banjir di Kota Medan belum optimal dilakukan. Kondisi tersebut dipengaruhi tidak adanya pemahaman terhadap kewenangan dan tidak terjalinnya koordinasi antara instansi terkait untuk menjaga daerah aliran sungai, normasilasi sungai dan memenetapkan saluran drainase primer. Selain itu, koordinasi kelembagaan pengendalian banjir Kota Medan dalam skema kerjasama Mebidangro sudah dilakukan secara prosedur. Namun dalam dalam aktualisasinya masih membutuhkan kepemimpinan yang visioner dan komando untuk mendukung keberhasilan program.
\end{abstract}

Kata kunci: Koordinasi Kelembagaan; Pengendalian Banjir; Mebidangro

\section{INTRODUCTION}

Some developed countries have paid attention to environmental issues, especially the increasing number of urban flood disasters (Karamouz, 2013). The phenomenon, caused by changing climate conditions, population growth and both have a negative impact on the environment (Saud, 2015). Therefore, the lack of awareness of the Regional Head in flood management planning, often raises problems related to the implementation established policies (Ridho, 2016). Nevertheless, institutional coordination in flood prevention and control is very important to be formulated to deal with every disaster event (Averus, 2013).

Currently flood management system in Medan is very poor and the lack of coordination is caused by sectoral egos. Therefore, effective institutional coordination in urban flood management is more needed. This condition, influenced by flood problems in the city of Medan that has not been effective actualization. Therefore, alternative solutions are needed for integrated urban flood management. Here's table 1. data on flood disasters at Medan City on 20152019. 
Table 1. Flood Disaster at Medan city in 2015-2019

\begin{tabular}{|c|c|c|c|c|c|c|}
\hline \multirow{2}{*}{$\mathrm{NO}$} & \multirow{2}{*}{ Region } & \multirow{2}{*}{ Year } & \multirow{2}{*}{ Number Incident } & \multicolumn{2}{|c|}{ Fatalities } & \multirow{2}{*}{$\begin{array}{c}\text { Submerged House } \\
\text { / Unit }\end{array}$} \\
\hline & & & & Deceased / Soul & Displaced / Soul & \\
\hline 1 & Medan City & 2015 & 4 & 0 & 14,817 & 9,000 \\
\hline 2 & Medan City & 2016 & 2 & 0 & 64,990 & 3,770 \\
\hline 3 & Medan City & 2017 & 6 & 2 & 19,154 & 4,272 \\
\hline 4 & Medan City & 2018 & 5 & 0 & 23,323 & 3,135 \\
\hline 5 & Medan City & 2019 & 2 & 0 & 0 & 1,121 \\
\hline
\end{tabular}

Data table 1. shows the last 5 years of the occurrence of 19 cases of flood disaster in the city of Medan. The condition resulted in 122,284 people being displaced and 20,117 houses submerged (BNPB, 2020). Flood disaster in The City of Medan mostly occurred along the Deli River, starting from the mountains of Bukit Barisan with an altitude of $1725 \mathrm{~m}$ above sea level to the coast of the Malacca Strait with a length of $75.8 \mathrm{~km}$, flowing through the city of Medan which is in the downstream of the Deli watershed with an altitude of about $0-40 \mathrm{~m}$ above sea level and has an area of $481.62 \mathrm{~km}$. This river is the main channel that supports the drainage of Medan city with an area of about $51 \%$. Handling the flood problem of Medan city has only been focused on the river flow only, but has not touched on the maintenance work of upstream watershed (Hasibuan, 2008) "abstract": "Flood control system from time to time has undergone through many perplexing changes as effect of sectoral ego, regional or local autonomy and unclear jurisdiction management boundary especially institutional coordination of administrative area (district/city.Meanwhile, Mebidangro urban area has been made a National Strategic Area through Presidential Regulation No. 62 of 2011 on Spatial Plan of Medan Urban Area, Binjai, Deli Serdang and Karo (Putra, 2017). The regulation requires that drainage network systems be carried out for flood management in residential areas, industrial estates, commercial areas and office areas. This policy aims to have primary drainage channels implemented in an integrated manner with flood control systems. Moreover, Law Nomot 23 of 2014 enlarges the authority Governor of North Sumatra to carry out the coordination function in overcoming floods in the city of Medan (Nasution, 2019). Thus, the city of Medan in the Spatial Plan of North Sumatra Province can be used as center of development of Mebidangro area (Alamsyah, 2018).

Flooding in Medan and surrounding areas received serious attention from Provincial Government of North Sumatra (Kompas.com, 2018). This condition is influenced by city of Medan as capital city that is the benchmark for success of vision and mission Governor of North Sumatra (Nasution,
2020). Furthermore, the handling of flood problems in city of Medan, was edicted by Establishment of an Integrated Coordination Team for Flood Management of Medan and surrounding areas with the Decree of the Governor of North Sumatra Number 188.44/411/ KPTS/2019 (Diskominfo.SumutProv，2019). So existence of an integrated coordination team and a budget of 12.4 billion for the flood-free city of Medan in 2022 must be done immediately (Ikhwan, 2019). However, until now the flood management program in Medan has not been implemented, because Provincial Government of North Sumatra is still focused on handling the Covid-19 pandemic (Arfah, 2020).

Related to previous studies, there has been a lot of analysis of institutional coordination problems. However, in reality issue of institutional coordination in flood control to date is still a crucial issue. Thus, huidobro's study found institutional characteristics affect the organization's capacity to address flood risk in flood-prone Hong Kong, Guangzhou and Rotterdam Delta Cities that are vulnerable to flooding. Furthermore, Karamouz's research reveals modified urban watersheds, can reduce flood volume and improve the reliability of drainage systems (Karamouz, 2013). In addition, Michael Obeta's research shows the Lagos state government organizes institutions and coordinates activities to address flood disasters (Obeta, 2014).

Furthermore, Dewi's thesis identifies institutional factors as the main requirement in improving flood management in Cilung-Cisadane river(Rooijen, 2017). Lebel's research shows institutional response, program information, implementing cottonistas and organizational fragmentation as the cause of flood vulnerability in Thailand (Lebel, 2010). Schaer's investigation resulted in a framework and institutional strengthening of the Central and City Governments as a solution to flood disaster in senegal (Schaer, 2017). Thus, author will explain the implementation of flood control policies in the city of Medan and how the institutional coordination of flood control in the city of Medan in the scheme of cooperation Mebidangro. Because based on Presidential Regulation No. 62 of 2011 and Establishment of Integrated Coordination 
Team still has obstacles in actualization of flood management in the city of Medan.

This research is expected to contribute to previous research, because this research has advantages from previous research. The savings can be seen in city of Medan there is no relevant institutional coordination to be applied in flood control, although the central government and local governments have required managing watersheds, but in practice still found some obstacles. Therefore, this research is important to be done in order to provide an overview of Institutional Coordination of Flood Control in the City of Medan in the Mebidangro Cooperation Scheme.

\section{METHOD}

This research uses qualitative research with descriptive methods to analyze cases (Moleong, 2017). Focus this research analyzes implementation of flood control policies in Medan City and institutional coordination of flood control in Medan City mebidangro cooperation scheme. Research locus are found in 21 subdistricts in Medan Ciy. Primary data collection techniques with deep interviews through FGD activities totaling 7 people (Creswell, 2016). Thus, FGD participants include; Secretary Integrated Coordination Team for Flood Management of Medan City, Chairman North Sumatra National Disaster Management Agency, North Sumatra Research and Development Agency Apparatus, Director North Sumatra Environment Rides, Head of Program and Planning Department of Monitoring Evaluation North Sumatra Environment Rides, Environmental Experts and Public Policy Experts. In addition, skunder data by citing journals, books, documents, online media, as well as other materials that can support research. Data analysis techniques include data reduction, data display and drawing conclusions (Miles \& Huberman, 2014).

\section{RESULTS AND DISCUSSION}

\section{Mebidangro Regional Spatial Plan Concept}

The national spatial policy North Sumatra Provincial Government area places Mebidangro as center of national activities and national strategic area. Regulation serves as a means of coordinating implementation of development in Mebidangro region. Mebidangro area of 301,697 ha which includes of Medan City, Binjai City, Deli Serdang Regency and Karo Regency. The purpose of Mebidangro spatial planning is to make area safe, comfortable, productive, internationally competitive, quality urban environment and watershed water balance, as well as sustainable utilization of natural resources. Furthermore, development plan of Mebidangro as a center of national activities and national strategic area has been prepared until 2030 (Perpres RI 62, 2011)

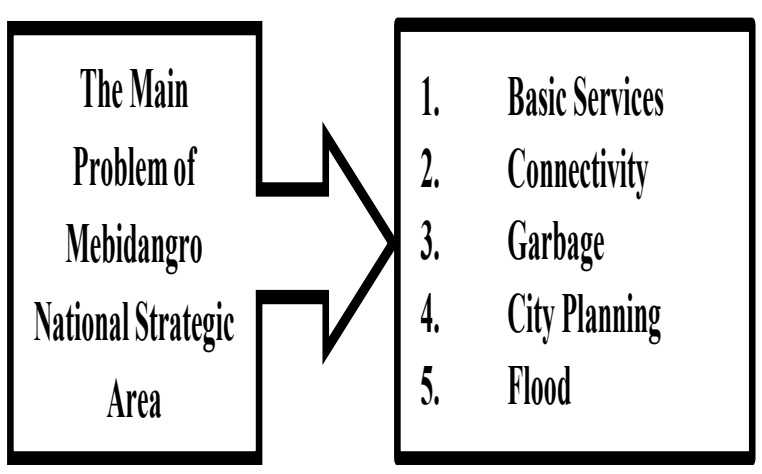

Source: Medan Flood Management Coordination Team, 2020

Figure 1. Main Problem of Mebidangro National Strategic Area

The description main problems national strategic area of Mebidangro contained in figure 1, among others;

1. Basic Services: Quantity, quality raw drinking water is minimal and the distribution of piping drinking water has not been evenly distributed.

2. Connectivity: Congestion growth urban centers of Mebidangro area is increasing, because there is no balance of quality and quantity of Provincial roads and District / City mebidangro.

3. Trash: The establishment of regional waste landfill and $3 \mathrm{R}$ waste management (reduce, reuse, recyle).

4. City Planning: Urban planning has not been maximal because the lack of public open space and sports facilities.

5. Flooding: narrowing land function of watershed areas due to improvement built-up area and flood control infrastructure is not optimal.

\section{Implementation of Flood Control Policy in Medan City}

Presidential Regulation No. 62 of 2011 in article 41 paragraph 5 stipulates that water resources infrastructure is carried out for flood control systems, irrigation network systems, swamp network systems, and coastal security systems. In addition, flood control systems in Mebidangro area are form of reservoirs, canals and retention ponds. Furthermore, primary drainage channels are established in order to reduce inundation and support flood control. Therefore, drainage channels are developed through main sewer and implemented in an integrated manner with flood control systems. Supporting regulations in flood management in Medan City are contained in table 2, although actualization is not optimal, among others: 
Table 2. Regulations Supporting Flood Control in Medan

\begin{tabular}{|c|c|c|}
\hline No & Regulation & About \\
\hline 1 & Law Number 24 of 1956 & $\begin{array}{l}\text { Establishment of Atjeh } \\
\text { Province Autonomous Region } \\
\text { and Changes in Regulation of } \\
\text { The Establishment of North } \\
\text { Sumatra Province }\end{array}$ \\
\hline 2 & $\begin{array}{l}\text { Presidential Regulation } \\
\text { Number } 62 \text { of } 2011\end{array}$ & $\begin{array}{l}\text { Mebidangro Urban Area } \\
\text { Spatial Plan }\end{array}$ \\
\hline 3 & Law Number 23 of 2014 & Local Government \\
\hline 4 & $\begin{array}{l}\text { Local Regulation Number } \\
2 \text { of } 2017\end{array}$ & $\begin{array}{l}\text { About RTRW North Sumatra } \\
\text { Province Year 2017-2037 }\end{array}$ \\
\hline 5 & $\begin{array}{l}\text { Governor Regulation } \\
\text { Number } 5 \text { of } 2016\end{array}$ & $\begin{array}{l}\text { About the Establishment of } \\
\text { Institutional Cooperation in } \\
\text { Urban Area Management } \\
\text { Mebidangro }\end{array}$ \\
\hline
\end{tabular}

Source: Processed data

Flood phenomenon main problem faced by the city of Medan, because flood disasters are not only influenced by high rainfall but several other factors that occur. There are 4 main causes of flooding obtained from the Combined Coordiation Team for Flood Management in Medan, among others; First, flooding of river overflows due to reduced river capacity caused by sedimentation against damage to watersheds and garbage dumps. Second, urban drainage has not been optimal, this condition is influenced poor arrangement and management of urban drainage, and has not fully built a drainage delivery (secondary drainage) to the river. Third, ROB floods often occur caused by the influx of sea water at high tide in the Area of North Medan (Belawan and its surroundings). Fourth, social problems are influenced by weak public awareness of river cleanliness and environment, weak law enforcement in controlling and securing river borders, and widespread settlement of residents living on banks and river borders.

14 FITIK WILAYAH RAWAN BANJIR/GENANGAN KOTA MEDAN DAN KABUPATEN DELI SERDANG

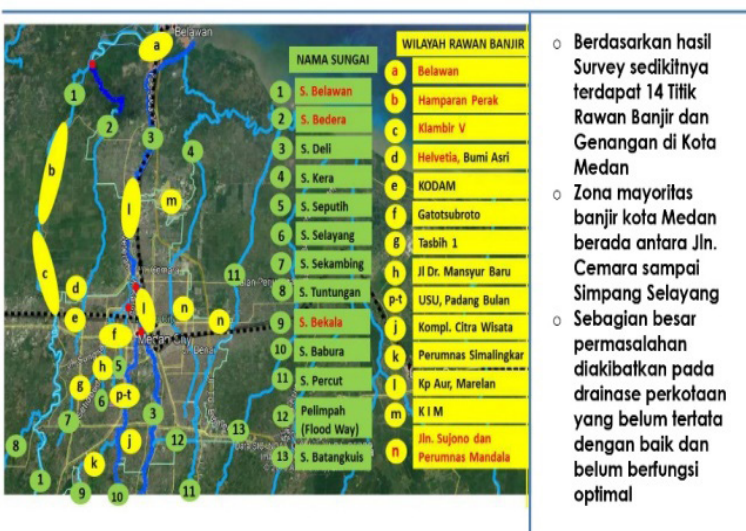

Source: Coordination Team for Flood Management of Medan City, 2019

Figure 2.14 Points of Flood Prone Areas of Medan City
Based on research Integrated Coordination Team of Flood Control of Medan City in figure 2 there are 14 flood prone points in Medan City. The area, caused by 13 rivers that cross the city of Medan surrounding Deli Serdang Regency is not able to accommodate the amount of water discharge. This condition, caused by serious sedimentation that resulted in the shallowing of several rivers in Medan City. Moreover, Sumatra River Regional Hall II does not manage and supervise wild buildings along the riverbank. Save the author in line with J.A's statement as An Environmental Expert in North Sumatra who said: "Some rivers in the city of Medan are not functioning, as evidenced by 95\% deli river and Badera river has been shallow and has been happening since 2011, in addition, which damaged some of these rivers is the Sumatra River Regional Hall II (BWSSII), they fortify this river with buildings, therefore there is no more water absorption and the absence of BWSS II's role in flooding, since the dutch era of canals and trenches have never been dredged or managed, this data I obtained from monitoring for last 6 years".

Furthermore, Medan City is crossed by several large rivers and tributaries, but the Deli, Badera and Babura rivers show one of the rivers that often experience flooding. The reduced capacity in river is influenced by number of settlements area riverbank worsening the problem of flooding. Therefore, Sumatra River Regional Hall II has authority over implementation of river dredging, but is often constrained in accessing heavy equipment influenced by number of community settlements. So that Medan Government must be able to guarantee the availability and sustainability of road access, and can reallocate community settlements to rusunawa or land compensation (TKPSDA, 2018). The opinion is in line with the statement of I.S.H as the Government Of North Sumatra Provincial Government, said: "The narrowing of the watershed, caused by the settlement of residents in the water absorption area, so far the North Sumatra Provincial Government has a Sumatra River Region Hall II (BWSS II), but that inhibits the normalization process influenced by this agency does not understand its authority. Normalization of the river is the full authority of BWSS II, therefore the coordination team for flood management of Medan City must be able to coordinate between BWSS II and the Medan Government so that some rivers can be normalized".

Mapping location of puddles in Medan for emergency preparation is important to do. Not denying that the switch of the function of the infiltration area into a settlement also contributed 
to the quantity of flooding Medan City. In addition, increasing population growth along banks river also has potential to cause narrowing river. Thus, implementation of Presidential Regulation Number 62 of 2011 on Mebidangro for flood control in Medan City has not been optimally carried out. Because there is no coordination between the Government of North Sumatra Province, Sumatra II River Regional Hall, Medan City Government and Deli Serdang Regency Government to maintain the watershed and there is no understanding related to the authority owned in normalizing river, establishing primary drainage channels to support flood management in Medan City.

\section{Institutional Coordination of Flood Control in Medan}

The problem of flooding in Medan City to date has not been carried out in an integrated manner. This condition, causing the city of Medan every year experienced quite severe flooding. Medan city should not be in flood-prone condition, if the handling of river watershed and urban drainage function properly. Thus, flood management in Medan and surrounding areas requires coordination between the Central Government, Provincial Government of North Sumatra, Medan City Government and Deli Serdang Regency Government. Writers thrifty can be proven by statement of R.A.L. as Secretary Team Integrated Coordination for Flood Management of Medan City and Surrounding Areas said: "Mebidangro area in flood management must be done with coordination between agencies, because this KSN is a national policy but until now has not been made a priority by the central government, for that there must be political pressure to implement this Mebidangro, both from the central government, Province, District / City".

According Manullang that coordination as an effort to direct activities towards organizational units in achieving the goals that have been set. Furthermore, institutional coordination can be done through 4 ways, among others: First, holding an official meeting between elements or units that must be coordinated. Second, appoint a person, a team or coordinating committee specifically tasked with coordinating activities. Third, create a handbook that contains an explanation of the tasks of each unit. Fourth, leadership held a meeting in order to provide guidance, consultation, and briefing (Manullang, 2008).

Governor of North Sumatra has coordinated institutionally through 4 stages as manullang opinion. First, Governor of North Sumatra held an official meeting with the Sumatra River Regional Hall II, Medan City Government, Deli Serdang Regency
Government to find a solution to flooding in Medan (Sentralberita, 2019). Second, this commitment is proven by the establishment of an Integrated Coordination Team for Flood Management in Medan and surrounding areas, and a working group is formed covering 10 fields. Third, first meeting on July 7 year 2019 Secretary of the Team Riadil Akhir Lubis has confirmed that this activity was followed by all team to explain purpose of each work program (Ikhwan, 2019). Fourth, Governor of North Sumatra and Secretary of Coordination Team for Flood Management in Medan and Surrounding Areas have provided direction to Sumatra River Regional Hall II, Ministry of Environment and Forestry, Government of North Sumatra Province, Medan City Government and Deli Serdang Regency Government to overcome flooding in Medan City (KIM, 2020). Here is table 3 data about on coordination and division of duties to several related agencies.

Table 3. Coordination and Division of Duties to Several Agencies

\begin{tabular}{|c|c|c|}
\hline No & Agency & Coordination And Duties \\
\hline 1 & $\begin{array}{l}\text { Sumatra River Regional } \\
\text { Hall II }\end{array}$ & $\begin{array}{l}\text { 1. River Management } \\
\text { 2. Primary Drainage } \\
\text { Development }\end{array}$ \\
\hline 2 & $\begin{array}{l}\text { Ministry of Environment } \\
\text { and Forestry of the } \\
\text { Republic of Indonesia }\end{array}$ & $\begin{array}{l}\text { 1. Land And Water } \\
\text { Conservation } \\
\text { 2. Watershed Management }\end{array}$ \\
\hline 3 & $\begin{array}{l}\text { Provincial Government } \\
\text { of North Sumatra }\end{array}$ & $\begin{array}{l}\text { 1. River Management and } \\
\text { Inter-District/City Secondary } \\
\text { Drainage Development } \\
\text { 2. Coordination, Land } \\
\text { Acquisition Support, } \\
\text { Population Relocation, } \\
\text { Facilitation of Housing } \\
\text { Provision }\end{array}$ \\
\hline 4 & $\begin{array}{l}\text { Medan City } \\
\text { Government and Deli } \\
\text { Serdang Regency } \\
\text { Government }\end{array}$ & $\begin{array}{l}\text { 1. Urban Drainage } \\
\text { Development (Secondary, } \\
\text { Tertiary and Environmental) } \\
\text { 2. Community Socialization } \\
\text { 3. Land Acquisition Support } \\
\text { For Rural Development } \\
\text { 4. Land Use and Settlement } \\
\text { 5. Social and Environmental } \\
\text { Issues }\end{array}$ \\
\hline
\end{tabular}

Source: Medan Flood Management Coordination Team, 2019

The short-term action plan for 2019-2022 that has been prepared by Coordination Team for Flood Management of Medan and Surrounding Areas for give recommendations to related agencies, in form of physical and non-physical development, among others, in table 4.

Institutional coordination of flood control at Medan City in Mebidangro scheme has been carried out procedurally. However, there are obstacles in the success of the flood-free Medan program in 2022. Based results of FGD in a broad show that 
there needs to be leadership visionary and command in conduct integration and coordination toward overcoming floods in Medan City. This condition is caused by stakeholders only making flood control programs as project oriented. Thus, authority of Governor of North Sumatra as a representative central government have should shown its leadership visionary and command in coordinating to Sumatra River Regional Hall II, Medan City Government and Deli Serdang regency Government towards flood management in Medan City. Author analysis based on R.A.L statement as Integrated Coordination Team for Flood Management of Medan city and its Secretariat that said; "'All these problems institutionally do not occur, because all relevant agencies do not understand the existence of their authority. Such as the role of the province and the center, as well as absence of the role of Sumatra River Regional Hall II and often programs carried based project oriented. Thus, there is no leader who is able to implement it. Only the organizational structure is established, but there is no clear command, for that much needed leadership Governor of North Sumatra. Because rivers that pass Medan city is aouthority government central. Example case of Mayor Medan when asked, saying it is not his authority, this should not be an excuse, this should Mayor be able to initiate and give recom to central government".".

Table 4. Short-Term Action Plan 2019-2022

\begin{tabular}{|c|c|c|}
\hline No & Fisik & Non Fisik \\
\hline 1 & $\begin{array}{l}\text { The creation of boundary } \\
\text { pegs, land acquisition and } \\
\text { relocation of residents on the } \\
\text { border of the river. }\end{array}$ & $\begin{array}{l}\text { Socialization to people } \\
\text { living on the banks / borders } \\
\text { of the river to prepare for } \\
\text { relocation. }\end{array}$ \\
\hline 2 & $\begin{array}{l}\text { Construction of residential } \\
\text { homes for relocation of } \\
\text { residents. }\end{array}$ & $\begin{array}{l}\text { Socialization to the } \\
\text { community so as not to } \\
\text { conduct activities that narrow } \\
\text { flow of rivers and maintain } \\
\text { cleanliness of environment } \\
\text { and rivers, as well as drainage. }\end{array}$ \\
\hline 3 & $\begin{array}{l}\text { Increased river storage } \\
\text { capacity (normalization, } \\
\text { construction of } \\
\text { embankments and gates, as } \\
\text { well as water pumps). }\end{array}$ & $\begin{array}{l}\text { Relocation of residents } \\
\text { (construction / provision } \\
\text { of housing for relocated } \\
\text { residents / temporary } \\
\text { housing rental / rusunawa). }\end{array}$ \\
\hline 4 & $\begin{array}{l}\text { Increase capacity of main } \\
\text { drainage, secondary / } \\
\text { cross districts / cities and } \\
\text { tertiary drainage. (reviewing } \\
\text { the restructuring and } \\
\text { revitalization of the City } \\
\text { drainage system including the } \\
\text { Flood canals). }\end{array}$ & $\begin{array}{l}\text { Strengthening regulation and } \\
\text { enforcement of rules related } \\
\text { to river border security, } \\
\text { environmental cleanliness, } \\
\text { building and settlement } \\
\text { arrangement. }\end{array}$ \\
\hline 5 & $\begin{array}{l}\text { Creation of information } \\
\text { boards and prohibition } \\
\text { boards on riverbanks and } \\
\text { drainage. }\end{array}$ & \\
\hline 6 & $\begin{array}{l}\text { Arrangement of river } \\
\text { borders and breeding areas. }\end{array}$ & \\
\hline
\end{tabular}

Source: Medan Flood Management Coordination Team, 2019
Problem of flooding in the city of Medan has become a cross-sector issue. Preparing institutional coordination on flood control is important (Sukayat, 2020). The fact that many resources are deployed such as human resources, equipment, technology, and budget for disaster management has not been able to overcome floods in the city of Medan (Molana, 2020). On December 3, 2020, 7 out of 21 sub-districts of Medan experienced severe flooding. These conditions, causing damaged houses, deaths and disappearances triggered by heavy rains, and rivers unable to accommodate water discharges (Detik.com, 2020).

Factors that influence the effectiveness of coordination of flood control in the city of Medan include authority, communication, control and leadership. Authority related to who has authority in flood control. Institutional strengthening of control of The City of Medan requires institutional structures from the central, provincial, to regency / city levels (Budiningsih, 2017). Moreover, Law Numbe 23 of 2014 on Local Government provides opportunities for provinces, kapubaten and cities to overcome flood control in the city of Medan. The Regional Head as a representative of the government in the Province is responsible to the President. His position as a representative of the government in the region, the Provincial Head has his own duties and authorities.

Law No. 23 of 2014 in Article 91 to Article 93 regulates the authority of the Governor as a representative of the central government to conduct coaching, supervision, monitoring, evaluation and supervision of assistance duties in the District / City. In addition, evaluating APBD, can cancel district/ city regulations and give approval to the Regional Peranturan Draft, as well as provide sanctions to the Regent / Mayor. In terms of carrying out the role of Deputy Central Government, the Governor's relationship with the district /city government is hierarchical. Therefore, the leadership of the Governor of North Sumatra in overcoming floods in the city of Medan became a benchmark for the success of the program. So that it can break the sectoral ego chain between districts / cities in maintaining watersheds, normalizing rivers and relocating residents.

The great authority of the Governor of North Sumatra as a representative of the Central Government aims to organize a cleaner, effective, efficient and put forward new public service to the community. The authority, as well as overcoming institutional coordination of flood control in the city of Medan in the scheme of cooperation Mebidangro. The complexity of governance issues in North Sumatra Province gives an idea that the meaning of 
institutional coordination should be implemented with a comprehensive approach. Therefore, it covers all elements, planned, measured, participatory, implementatively sustainable, and pay attention to the principles of cooperation.

\section{CONCLUSION}

The results showed that implementation of Presidential Regulation Number 62 of 2011 against flood control in Medan city has not been optimally carried out, because there is no coordination between Government of North Sumatra Province, Sumatra River Regional Hall II, Medan City Government and Deli Serdang Regency Government for maintain watershed. Moreover, there is no understanding related to authority owned in normalizing the river, establishing the primary drainage channel of the river in the city of Medan. In addition, institutional coordination of flood control in The City of Medan in the Mebidangro cooperation scheme has been carried out in a procedural. It appears that the Governor of North Sumatra held an official meeting to the stakeholders, formed an Integrated Coordination Team for Flood Management in Medan and Surrounding Areas, have make duties and functions of each unit and provided guidance, as well as a briefing to stakeholders to overcome floods. But in its actualization still requires leadership visionary and command in supporting the success of program.

\section{ACKNOWLEDGMENTS}

The thank you is primarily directed to the University of North Sumatra Research Institute which has funded this research through the 2020 Young Lecturer/ Beginner Research scheme with non PNBP funding source Of University of North Sumatra Fiscal Year 2020. In addition, thank you to all those who have helped with the research, so that this research can be completed properly.

\section{REFERENCES}

Alamsyah, B. (2018). Penanganan Problematik Banjir Kota Medan Berdasarkan Pendekatan Partisipasi Masyarakat. Jurnal Pembangunan Perkotaan, 6(2), 95-101.

Arfah, A. (2020). Program Tangkal Banjir di Medan Terhambat, Gubsu Edy: Kita Fokus Corona. Detik News, p. 1. Diakses 23 September 2020. Retrieved from https://news.detik.com/ berita/d-5063828/program-tangkal-banjir- di-medan-terhambat-gubsu-edy-kita-fokuscorona

Averus, A. \& Pitono, A. (2013). Pengaruh Implementasi Kebijakan Pertambangan Terhadap Efektivitas Penanganan Kualitas Lingkungan Hidup pada Dinas Pekerjaan Umum, Energi dan Sumber Daya Mineral Kota Palu. Sosiohumaniora, 15(2), 119-129. https://doi.org/10.24198/sosiohumaniora. v15i2.5738

BNPB. (2020). Bencana Alam Menurut Wilayah Kab/Kota (Medan) Tahun 2015 S/D 2019. Diakses 11 Oktober 2020. Retrieved from http://bnpb.cloud/dibi/tabel2a

Budiningsih, K. (2017). Implementasi Kebijakan Pengendalian Kebakaran Hutan Dan Lahan Di Provinsi Sumatera Selatan. Jurnal Analisis Kebijakan Kehutanan, 14(2), 165-186. https://doi.org/10.20886/jakk.2017.14.2.165186

Creswell, J. W. (2016). research design, pendekatan metode kualitatif,kuantitatif dan campuran (1st ed.). Yogyakarta: Pustaka Pelajar.

Detik.com. (2020). 12 Fakta Terkini Banjir Setinggi Atap di Medan. Detik News, p. 1. Diakses 21 Desember 2020. Retrieved from https://news. detik.com/berita/d-5282314/12-fakta-terkinibanjir-setinggi-atap-di-medan?single $=1$

Diskominfo.sumutprov. (2019). GUBSU, Bentuk Tim Koordinasi Terpadu Penanggulangan Banjir Kota Medan dan Sekitarnya. Diskominfo.Sumutprov.Go.Id, p. 1. Diakses 20 September 2020. Retrieved from https:// diskominfo.sumutprov.go.id/artikel-1728gubsu-bentuk-tim-koordinasi-terpadupenanggulangan-banjir-kota-medan-dansekitarnya.html

Hasibuan, G.M. (2008). Model Koordinasi Kelembagaan Pengelolaan Banjir Perkotaan Terpadu. Wahana Hijau, Jurnal Perencanaan \& Pengembangan Wilayah, 3(3), 116-126. https://doi.org/http://repository.usu.ac.id/ handle/123456789/17944

Ikhwan, K. (2019). Pemprov Sumut Siapkan Anggaran Rp 12,4 M untuk Tangani Banjir Medan. Detik News, p. 1. Diakses 15 Agustus 2020. Retrieved from https://news.detik.com/ berita/d-4636572/pemprov-sumut-siapkananggaran-rp-124-m-untuk-tangani-banjirmedan 
Karamouz, M. \& Nazif, S. (2013). Reliability-Based Flood Management in Urban Watersheds Considering Climate Change Impacts. Journal of Water Resources Planning and Management, 139(5), 520-533. https:// doi.org/10.1061/(ASCE)WR.1943 5452.0000345

KIM. (2020). Coordination Meeting of River Flood Control at Modern Industrial Estate. Accessed January 04, 2020. Retrieved from https:// kim.co.id/new/en/news/detail/coordinationmeeting-of-river-flood-control-at-modernindustrial-estate/

Kompas.com. (2018). Cerita Gubernur Sumut Edy Rahmayadi Tegur Kepala Dinas Saat Banjir di Dekat Kantor Gubernur. Kompas. Com, p. 1. Diakses 28 Desember 2020. Retrieved from https://medan.kompas.com/ $\mathrm{read} / 2018 / 10 / 12 / 09011601 /$ cerita-gubernursumut-edy-rahmayadi-tegur-kepala-dinassaat-banjir-di-dekat?page $=$ all

Lebel, L., Manuta, J.B. \& Garden, P. (2010). Institutional traps and vulnerability to changes in climate and flood regimes in Thailand. Regional Environmental Change, 11, 45-58. https://doi.org/10.1007/s10113-010-0118-

Manullang. (2008). Dasar-Dasar Manajemen. Yogyakarta: Ghalia Indonesia.

Miles, M.B., Huberman, M. \& Saldana. (2014). Qualitative Data Analysis: A Methods Sourcebook. (H. Salmon, Ed.) (3rd ed.). London: SAGE.

Molana, D.H. (2020). Gubsu soal Medan Banjir Lagi: Sungai Harus Dinormalisasi, Masih Proses. Detik News, p. 1. Diakses 03 Januari 2020. Retrieved from https:// news.detik.com/berita/d-5311956/ gubsu-soal-medan-banjir-lagi-sungaiharus-dinormalisasi-masih-proses? $\mathrm{ga}=2.248402754 .473836368 .1610005680-$ 1872279658.1547480511

Moleong, L.J. (2017). Metodologi Penelitian Kualitatif (27th ed.). Bandung: Remaja Rosdakarya.

Nasution, F.A. \& Kushandajani, K. (2019). Partisipasi Politik Masyarakat Kecamatan Medan Maimun Pada Pemilihan Gubernur Sumatera Utara Tahun 2018. JPPUMA Jurnal Ilmu Pemerintahan Dan Sosial Politik Universitas Medan Area, 7(2), 227-235. https://doi. org/10.31289/jppuma.v7i2.3015
Nasution, F.A. (2020). Menakar Partisipasi Politik Masyarakat Kota Medan Terhadap Pemilihan Walikota Medan Tahun 2020: Indonesia. Politeia: Jurnal Ilmu Politik, 12(2), 97-113. Retrieved from https://talenta.usu.ac.id/ politeia/article/view/3955

Obeta, M.C. (2014). Institutional Approach to Flood Disaster Management in Nigeria: Need for a Preparedness Plan. Current Journal of Applied Science and Technology, 4(33), 4575-4590. https://doi.org/10.9734/BJAST/2014/11844

Perpres RI 62. Peraturan Presiden Republik Indonesia Nomor 62 Tahun 2011 Tentang Rencana Tata Ruang Kawasan Perkotaan Medan, Binjai, Deli Serdang, Dan Karo, Pub. L. No. 62, 123 (2011). Indonesia. Diakses 21 Agustus 2020. Retrieved from https://peraturan.bpk. go.id/Home/Details/41180/perpres-no-62tahun-2011

Putra, M., Giyarsih, S.R. \& Kurniawan, A. (2017). Sektor Unggulan dan Interaksi Antarwilayah pada Kawasan Strategis Nasional Perkotaan MEBIDANGRO. Jurnal Wilayah Dan Lingkungan, 5(3), 181-187. https:/doi. org/10.14710/jwl.5.3.181-187

Ridho, H. \& Nasution, M.A. (2016). Analysis of Community-Based Waste Management in Medan. In 1st International Conference on Social and Political Development (ICOSOP 2016). Atlantis Press. (pp. 513-516). https:// doi.org/10.2991/icosop-16.2017.70

Rooijen, K. van. (2017). Urban Governance in the Realm of Complexity. Inggris: PracticalAction. https://doi.org/10.3362/9781780449685.014

Al Saud, M. M. (2015). Flood Control Management for the City and Surroundings of Jeddah, Saudi Arabia. London: Springer. https://doi. org/10.1007/978-94-017-9661-3

Schaer, C.E.A. Schaer, C., Thiam, M.D. \& Nygaard, I. (2017). Flood management in urban Senegal: an actor-oriented perspective on national and transnational adaptation interventions. Climate and Development, 10(3), 1-17. https://doi.org/ 10.1080/17565529.2017.1291405

Sentralberita. (2019). Tahun 2022 Medan Menuju Bebas Banjir, Sebuah Komitmen Pengabdian Buat Rakyat. Sentralberita.Com, p. 1. Diakses 12 September 2020. Retrieved from https://sentralberita.com/2019/09/tahun2022-medan-menuju-bebas-banjir-sebuahkomitmen-pengabdian-buat-rakyat/ 
Sukayat, Y. (2020). Organizational Dynamics Of Communities For Water Users (Case in Cihea Irrigation Area, Ciranjang District, Cianjur Regency, West Java). Sosiohumaniora, 22(3), 365-374. https://doi.org/10.24198/ sosiohumaniora.v22i3.27446
TKPSDA. (2018). Buletin TKPSDA WS Belawan UlarPadang. Diakses4Januari2020. Retrieved from http://sda.pu.go.id/tkpsda/tobaasahan/ uploads/buletin/buletin_201708150025.pdf 